\title{
Áкоs KöHIDI* \\ Critical and Ameliorating Thoughts on Consumer Protection Concerning Product Liability
}

\begin{abstract}
In this paper the rules of product liability (the strict liability for defective products) will be discussed. Albeit the EU orders of this liability form were established more than twenty years ago, it is worth to explore that again, because new vital questions have arisen and arise nowadays, furthermore relevant essays were published on it, which emphasize the economic relations as well. The author has the intention to collect the most significant critical thoughts contrasting these with English and German studies, outline the problematic issues, loopholes, and experiences. Beyond the EEC Directive, the implemented rules in the acts of member states shall be cited and compared simultaneously.
\end{abstract}

Keywords: product liability, strict liability for defective products, negligence, deficient performance, development risks defence, alternative dispute resolution, immanent problems, reasonable man, Sale of Goods Act, Consumer Protection Act

\section{Introduction}

Consumer protection is really an emphatic policy issued by the European Union. The latest principal achievement in the Charter of Fundamental Rights of the European Union is the policy of consumer protection, stating that "Union policies shall ensure a high level of consumer protection", ${ }^{1}$ which stresses again the intention of a higher protection. It is logical and plausible, because an efficient internal market needs common consumer policy, hence the development of consumer protection law in the European Union since the beginning of the seventies.

Several rules, among others, of the Hungarian contract and tort law were changed under those EC directives, which had focused on the interest of consumers. New contract forms were established, for instance "door to door sale", "distance selling", "time-sharing", and thus traditional types have changed. We can detect basic changes in the field of liability, for instance in product liability, the EC legislation has changed the negligence base for these cases, and constituted a new strict liability form. I wish to highlight the system of strict liability for defective products, and draw attention to the practical problems and criticism of the regulation through a few cases and studies. Last but not least, I will summarize the predictable changes in the new Civil Code of Hungary. Can the law be the watchdog of people, who are not able to protect themselves against consumerism? It is still a vital question of this theme. Some studies (especially the thoughts of private lawyers) highlight the side-effects of this protection. The main problem is the artificial balance between the consumer and the seller or producer. The law is unable to make the consumer

* Assistant lecturer, Department of Civil Law and Civil Procedural Law, Faculty of Law, Széchenyi István University, H-9026 Győr, Egyetem tér 1; junior research fellow, Institute for Legal Studies of the Hungarian Academy of Sciences, H-1014 Budapest, Országház u. 30.

E-mail: kohidi@sze.hu

${ }^{1}$ Article 38 of the Charter of Fundamental Rights of the European Union, Official Journal C 83, 30.3.2010, 399 . 
smarter, it can only change the rules, within those the purchasers can enforce their rights. Why should a typical private law relation be modified with public law instruments? Is this the way of the future, or education, prevention? The EU wished to harmonise the national rules by setting minimum standards, yet why is it still disputed? One reason is the fact, that the model of the regulation is essentially based on the economical and legal traditions of welfare states. These rules can be barely implemented by the countries of Eastern Europe, but it does not change the fact that the consumer society is not sufficiently developed at the time of the implementation. It raises further but very significant questions, for instance: who is actually the ideal type of consumer, who is to be protected? The American type of consumer, a real Européer, the "reasonable man" or a Hungarian pensioner? We should avoid characterizing them as silly, reckless people, who cannot protect themselves, instead of developing a positive, self-conscious civilian ideal.

\section{The evolution of the strict liability concept}

In this study I try to embrace the main statements and critical opinions concerning product liability. First of all I want to discuss some aspects of the historical background, and the evaluation of this liability form. The so-called product liability (in other words: strict liability for defective products) has been adopted into the EU law with the Product Liability Directive 85/374/EEC. Before this directive none of the member states had special rules regarding the liability of the producer, only court decisions, which had established a higher protection and liability level (a specialized duty of care). ${ }^{2}$ Let me illustrate it with an early case from the United Kingdom.

Before the regulation in the United States or Europe began, there was a case in the United Kingdom, which was actually a forerunner of the present product liability form. ${ }^{3}$ This was the decision in the case Donoghue vs. Stephenson in $1932 .{ }^{4}$ In 1928 Donoghue and her friend took their seats in a cafe in Paisley. They ate ice cream, and the friend of Donoghue ordered a ginger beer. It was claimed that the remains of a snail in a state of decomposition dropped out of the bottle. After this incident Donoghue became ill, suffered from shock and complained of stomach pain and several other symptoms. She brought an action against the manufacturer, named Stephenson, and claimed 500 pounds as damages (which she was awarded). The dispute between Donoghue and Stevenson was eventually decided by the court in Donoghue's favour. "But in fact, the importance of the case went far beyond the correction of this wrong; it changed the distribution of wealth in society in a significant way by deciding that in future, manufacturers would have to bear costs associated with the manufacturing process which, on the assumption we have made, were previously borne by consumers". 5 This highlights some economical aspects of this topic, which I explain in details later.

One of the curiosities of this case was that the jury subsumed the "duty of care" doctrine without any contractual relationship between the two parties. Because Donohue was not the person, who ordered the ginger beer and neither did she pay for it. This concept existed before this case, but it was generally held that a "duty of care" was only owed in

2 Benacchio, G.: Az Európai Közösség Magánjoga (Private Law of the European Community). Budapest, 2003, 289, 241, 242.

${ }^{3}$ It should be noted that the decision was based on the general rule of negligence.

${ }^{4}$ See for the full description of the case http://www.leeds.ac.uk/law/hamlyn/donoghue.htm.

5 Cane, P.: The Anatomy of Tort Law. Oxford, 1997, 18. 
very specific circumstances, for instance where a manufacturer made dangerous products (the ginger beer was obviously not such a product) or was acted fraudulently. Thus the jury set aside the usual conditions, and developed the common law therefore. Consumers in the position of Donoghue could not recover damages from manufacturers in the position of Stevenson, while after the decision they could, thus it becomes clear that one result of the case was to alter the distribution of resources in society by giving consumers a right of action against manufacturers which they did not have before. ${ }^{6}$ It can be considered to be a revolutive change, because outsiders, such as the recipient of goods as a gift, or the user of goods, who was not also the purchaser, had no remedy in contract until the changes introduced by the Contracts (Rights of Third Parties) Act 1999. This Act, in certain circumstances, allows third parties to enforce or rely on contractual provisions. ${ }^{7}$

Product liability is a strict liability form for defective provision. In Hungary, there was a controversial issue by jurisprudence and praxis identifying the substance of product liability. Is it a contractual relationship between the two parties, or a delictual one? It had been determined as a delictual relation, and established a special liability form in a special Act X of 1993, which implemented the formerly referred EEC Directive. ${ }^{8}$ The new Hungarian Civil Code will probably contain this liability form, in the chapter of torts. ${ }^{9}$

Otherwise the former judicial practice usually emphasizes the delictual character of product liability. We can detect it in few court decisions, for example: it shall be owed the general duty of care standard, if the person or entity, who causes the damage, is a producer of a good, and the defect of this product is the cause of the damage. Notwithstanding the lack of a contractual relationship between the consumer and the producer, or rather the claimant can bring an action against third parties because of breaching the contract. The reference to the lock of relevant legal relation between the parties is incorrect, as the causation creates this relation itself (ergo the obligation between the consumer and the producer).$^{10}$ So the jury could determine stricter standard through subsuming the general rule of delictual liability: "A person who causes damage to another person in violation of the law shall be liable for such damage. He shall be relieved of liability if he is able to prove that he has acted in a manner that can generally be expected in the given situation." (Act IV of 1959, hereinafter: HCC) Therefore we can achieve the same result in different ways (via strict liability or subsuming the general rules. It should be noted that not all of the

${ }^{6}$ Ibid.

7 Harpwood, B.: Principles of Tort Law. London, 2000, 329.

8 Before 1993 in the Hungarian law it has not been decided that this kind of damages could be recovered under the Section 310 (on contractual base) or 339 (on delictual base) of the Hungarian Civil Code. The Hungarian courts usually based their decisions on delictual rules, for example, BH 1984/208. In Germany, the firstly preferred contractual or semi-contractual theories were considered and rejected by the Supreme Court in its decision of 1968. (See more: Markesinis, B. S.-Unberath, H.: The German Law of Torts. A Comparative Treatise. Oxford, 2002, 94-99; and "Liability for defective products is an area where contract and tort meet and overlap" see Samuel, G.: Tort: Cases and Materials. London, 2008, 183.)

9 The former Act on the new HCC (Act CXX. of 2009) had not come into force on schedule (1 May 2010) according to the decision of the Hungarian Consitutional Court. Let me conclude the taxonomical emplacement of this former Code, as to suspect the incorporation product liability and the further category of this institution.

10 BH 1986/12/501. 
states adopted the delictual concept. For instance, in France and USA the product liability was emplaced in the field of the contractual liability.

\section{Deficient performance}

Firstly, we should deal with the nature of deficient performance, because product liability is based on it. Deficient performance is, in short, the non-conformity of goods with the contract, which occurs if the parties owe mutual services to one another and the goods or provisions do not, at the time of performance, correspond to the characteristics stipulated by law or by the contract. For example, contract specifications can be sumptuous as well (for instance special colour or feature of the goods). The consumer needs to prove that the fault existed at the time of performance. However, the Directive 99/44 EC has changed this rule by means of a presumption, which I will review below. Thus who has to prove the time, when the goods became faulty? A rebuttable presumption of non-conformity was established for the first six months after the time of the performance. It is a form of strict liability (to be more exact: a duty), thus the obliged party cannot exculpate himself. However, the conformity can be proved, therefore the presumption can be rebutted, and the duty won't exist at all.

The obligee shall be entitled to request repair or replacement of the good according to his or her choice. Unless the choice is impossible or its accomplishment causes disproportional costs. If the obligor is unable to fulfill either of the former alternatives, the consumer can request appropriate price reduction or can rescind the contract. Both of these should obviously be fulfilled free of charge.

Furthermore, there is special three-day period for replacement in relation to goods designed for long term use. If the consumer bases his claim on this rule, the obligor cannot invoke disproportional costs. Except that the rights are the same regarding express and implied warranty. If the consumer signs a special consumer contract, he will be entitled to rescind the contract within a more favourable period without stating any reason. Last but not least, the consumer shall be entitled to claim damages, if damage has been caused, because deficient performance is a kind of breach of contract. There is a special commerce practice in Hungary, according to which the seller should refund the price if the contract is rescinded. But the Hungarian seller typically urges the consumer to purchase some other goods, because they do not wish to reimburse the customer. What can the consumer do? Basically, nothing, because it is not worth initiating a lawsuit in case of cheap goods.

What is the difference between the general rules of deficient performance and the rules of product liability? "The injured person shall be required to prove the damage, the defect and the causal relationship between defect and damage." 11 As we can see no such presumption exists, which can be especially problematic, because the burden of proof falls on the claimant and it can be difficult, especially in medical and pharmaceutical cases. ${ }^{12} \mathrm{It}$ is the first occasion, where the producer can find a loophole in the law, the second is definitely in the rules of development risk defence, which I explore later.

11 Article 4 of the Directive 85/374/EEC, we can find the same in Act X of 1993 of Hungary, or the Consumer Protection Act (1987) of UK, or the Produkthaftungsgesetz of Germany.

12 See, for exmple, the case Kay vs. Ayrshire and Arran Health Board (1987) cited by Woodroffe, G.-Lowe, R.: Consumer Law and Practice. London, 2010, 65. 
In which circumstances is the product defective? We can find different rules in the relating Directive ${ }^{13}$ and the Hungarian Product Liability Act. Let us see the former first:

A product is defective when it does not provide the safety which a person is entitled to expect, taking all circumstances into account, including:

(a) the presentation of the product;

(b) the use to which it could reasonably be expected that the product would be put;

(c) the time when the product was put into circulation.

The Hungarian Product Liability Act implemented these articles, but one extra condition was added to the former ones: a product is defective when it does not provide the safety which a person is entitled to expect, taking the state of scientific and technical knowledge into account. This provision is favourable to the consumer, because of the discussed rules of the burden of proof. Moreover the producer can refer to the state of scientific and technical knowledge to defend himself.

Differences could be detected concerning the concept of the defect in the rules of deficient performance and product liability. As it was stated, the defect means relating to deficient performance (and the consequence of this: several warranty and guarantee forms), if the provided goods do not, at the time of performance, correspond to the characteristics stipulated by law or by the contract. If the character is stipulated by the law itself, the general rules of performance should be invoked. Briefly these are the followings in the HCC: if the parties have not stipulated the quality of the object defined, performance must be made in accordance with commercially available things of standard good quality. ${ }^{14}$ Furthermore, services shall be suitable for their intended purpose or for use that is otherwise in conformity with the purpose known to the obligor at the time the contract is concluded. So the HCC states an average quality, if the parties do not stipulate specialized terms. Also, if the claimant proves the defect and therefore the breach of contract, it does not support the defect concerning product liability. The situation is different for instance in British law, where the definition of "defective goods" of the Consumer Protection Act (1987) is broadly similar to the definition of" satisfactory quality" of the Sale of Goods Act (1979).

\section{Immanent problems with the rules of product liability}

Turning to the scrutiny of the rules, let me outline and sum up the controversial articles regarding the cited liability form. J. Macleod summed up the chief problems, which arose in the United Kingdom and divided these into five several categories: the state-of-the-art issue, burden of proof, the cost of civil litigation, liability for acts of another, the international dimension. ${ }^{15}$ This division is fully asserted, and being applicable to describing a wider range of regulation, as for example the problems in other member states. Discussion of the problems of the last two issues is beyond the scope of this essay, because these are relating not immanent problems.

13 Section 3 of the Consumer Protection Act (1987) and the same Section of the German Produkthaftungsgesetz broadly follows the three main categories of Directive 85/374/EEC.

${ }^{14}$ See more in para. 277 of the HCC.

15 Macleod, J.: Consumer Sales Law. The Law Relating to Consumer Sales and Financing of Goods. London, 2002, 516. 
The relating directive creates a scheme of strict product liability for damage arising from defective products. The producer (or if the producer cannot be identified, each supplier of the product shall be treated as its producer unless he informs the injured person, within a reasonable time, of the identity of the producer or of the person who supplied him with the product) shall be liable for damage caused by a defect in his product. ${ }^{16}$ The liability of the supplier is consequently subsidiary (in addition joint and several), but it can be defended according to the Article 7 (which I review below in detail). This complex concept of the producer is not a satisfactory solution, if the manufacturer or the supplier will be terminated without a legal successor.

The liability, as I stated earlier, is a kind of strict liability, in Hungary that is to say objective liability. But the obligor can defend with reference to the Article 7:

The producer shall not be liable as a result of this Directive if he proves:

(a) that he did not put the product into circulation; or

(b) that, having regard to the circumstances, it is probable that the defect which caused the damage did not exist at the time when the product was put into circulation by him or that this defect came into being afterwards; ${ }^{17}$ or

(c) that the product was neither manufactured by him for sale or any form of distribution for economic purpose nor manufactured or distributed by him in the course of his business; or

(d) that the defect is due to compliance of the product with mandatory regulations issued by the public authorities; or

(e) that the state of scientific and technical knowledge at the time when he put the product into circulation was not such as to enable the existence of the defect to be discovered; or

(f) in the case of a manufacturer of a component, that the defect is attributable to the design of the product in which the component has been fitted or to the instructions given by the manufacturer of the product.

The reasoning of sections (a), (b) and (c) are logical and plausible. But the others are not so easy to justify, because these commands are not really favourable to the consumers. Firstly, we should explore section (e), which is in other words the development risks defence. The producers obviously have the pull over the consumers regarding the proving, because they know the construction process, the characteristics of the product. It is hard to imagine, that the claimant can successfully prove the contrary. (And it is not only about the fee of an expert. ${ }^{18}$ )

Therefore the risk of the scientific and technical development our Act in accordance with the regulation model of most states place upon the consumers. However, they feel it very much, because of their lower bearing capacity of economic sense. Non plus ultra, the producer can calculate the higher risk concerning the product liability with less effort,

16 Article 3 of Directive 85/374/EEC.

17 The origin of this article can be found in the case Grant v. Australian Knitting Mills of 1936, where the Court rejected the claim, and exlicated, that the maxim of res ipsa loquitur was inapplicable because the manufacturer loses control after the relase of the article upon the market and intermediaries handle it before it reaches the consumer.

18 We can face similar statements concerning the anglo-saxon praxis, where this trouble of proof is mentioned as the erosion of the principle res ipsa loquitur. Cp.: Harpwood: op. cit. 331. Furthermore the burden of proof regarding medical damages raises a lot of especially vital questions. 
through signing an insurance contract. On the contrary, not every citizen has personal insurance, nor a general asset insurance (various forms of insurance can be signed, but these probably do not cover every sort of damage). In summary we could likely state, that insurance is more readily available to the manufacturer than it is to the consumer. It is not a wonder, that Directive 85/374/EEC, the written origin of the regulation caused serious argument among the representatives of consumers and sellers. The reason being was that we could find in the draft of the Directive published in 1976 the following: the producers are also liable, if the state of scientific and technical knowledge at the time when they put the product into circulation was not such as to enable the existence of the defect to be discovered. The member states made a compromise at the end, therefore the directive gives member states the option of excluding the development risks defence, this is permitted in all member states except Luxembourg, Finland and Norway. Reasons can be found, why most states reserve the former type of defence. If it were not adopted, it would raise the prices, because the development defence would be calculated as a part of the price. Therefore a state without this defence can preserve or increase its competitiveness. ${ }^{19}$ "The development risk defence was the prime reason why the EC draft Directive took nearly ten years to become a Directive. There was strong lobbying from United Kingdom industries (especially pharmaceutical industries) on the basis that without such a defence, research and development would be severely hampered. The other side of the argument is equally compelling - such a defence would leave victims of a future Thalidomide-type tragedy without a remedy." 20

Furthermore, there is an other debuted form of defence that the defect is due to compliance of the product with mandatory regulations issued by the public authorities. The consumer can only claim against the state itself for damages caused by legislation.

The concept of damage is different than the generally used private law concept, this does not embrace every kind of damage. The damage caused by the defective ${ }^{21}$ product can be divided into two different categories ${ }^{22}$

- death or by personal injuries;

- damage to, or destruction of, any item of property other than the defective product itself, with a lower threshold of 500 EUR,

provided that the item of property: is of a type ordinarily intended for private use or consumption, and was used by the injured person mainly for his own private use or consumption.

It must be noted, that the damage should be caused to an item of property different from the item, which was the first link of causation (for example, the consumer is not

19 "Even the development risks defence was introduced into the legislation because of the selfinterest of the Conservative government which feared that British goods would not be competitive in Europe if price increases were required to meet the cost of insuring against liability for possible defects in newly developed products." See Harpwood: op. cit. 341.

20 Woodroffe-Lowe: op. cit. 72.

21 What is actually the product under the referred Act? According to it, any movable goods and the electricity. Albeit the groving crops and things comprised in land by virtue of being attached to it, and pharmaceutical products had been excluded, later these were included due to the consideration of the legislator. The definitions of the memberstates are really diversified (e.g. the groving crops are almost everywhere excluded, except Sweden and Luxembourg).

22 Article 9 of Directive 85/374/EEC. 
entitled to claim for damages relating to the damage of defect of the product itself, or the delay of repairing or replacing). ${ }^{23}$

Two cases around the former issue have been collected just for curiosity. In the one there was a component built into the car after finishing the original construction. Should the producer be liable for such a damage, which was caused by a fault in the original construction to the subsequently built in part? ${ }^{24} \mathrm{G}$. Woodroffe and R. Lowe give the example: " $\mathrm{C}$ buys a defective car. It crashes and injures. The car is a write-off. $\mathrm{C}$ can recover for his injuries but not for the cost of replacing the car." ${ }^{25}$ In my opinion, "C" shall be entitled to claim for damages to the car, just not under product liability rules, but the general rules of breaching the contract.

The source of the problem is the following. If defect of the final product, which a component built in subsequently, caused the damage, then-although product liability cannot be stated concerning the component-under the theory of complexity the product liability form cannot be adopted relating to the damage of the final, nor the component product. Because it cannot be determined as damage to another item of the property.

A contrario, would the producer be liable if the component caused a short circuit in the electric system of the vehicle and the damage is due to this fact? It is nearly impossible to answer this question. There are an infinite number of similar questions. Would the producer of the final product be liable, because the quality of the component should probably have been tested before building it in? Is it relevant, that the producer of the component considered the special instructions of the producer of the final product in the construction process? Who will be actually liable, if the damage is not caused directly through the defect of the component, but the way of building into the final product? ${ }^{26}$ The questions can only be answered case by case, not in general. The problem traces back to the concept of causation. It is not favourable for the consumer, because the causation - under the general rules of liability - shall be proved by the claimant. The dilemma exists in spite of the normative regulation. Para. 7(2) of Act X of 1993 or para. 1(3) of the German Produkthaftungsgesetz, for instance, stated in the same way, that the manufacturer of the component can defend himself, if he proves, that the defect is attributable to the design of the product in which the component has been fitted or to the instructions given by the manufacturer of the product. ${ }^{27}$

Turning back to the concept of damage, the economical loss cannot be requested under the cited Acts. Otherwise the actual damage can only be requested, if the product is of a type ordinarily intended for private use or consumption. As the former the following section is hard to be explained too: the product shall be used by the injured person mainly for his own private use or consumption. The reason is, that not only the consumers can become claimant, the legislator tried to impound the social relations, which aimed to be used. The privity was not created by a consumer contract between the claimant and the defendant,

${ }^{23}$ In the Anglo-Saxon praxis could these damages recovered, too, the so-called "pure economic loss" could be requested from the case Junior Books vs. Veitchi (1983) to the case Murphy vs. Brentwood DC (1990).

24 Cp.: Markesinis-Unberath: op. cit. 93.

25 Woodroffe-Lowe: op. cit. 69.

26 See more: Markesinis-Unberath: op. cit. 100-101.

27 "Die Ersatzpflicht des Herstellers eines Teilprodukts ist ferner ausgeschlossen, wenn der Fehler durch die Konstruktion des Produkts, in welches das Teilprodukt eingearbeitet wurde, oder durch die Anleitungen des Herstellers des Produkts verursacht worden ist." [ProdHaftG para. 1(3)]. 
therefore the inequality relation should have been considered by establishing the concept of the damage. It may have happened under too broad a meaning, the private person (who is actually a consumer in a contractual relation) cannot claim for damages to the items of the property, which ordinarily not intended for private use or consumption, but it was used mainly for his own private use or consumption. These kinds of problems can be raised, if objects are in the focal point of the regulation.

\section{Economical and critical theories}

Firstly, let me explain some dogmatic aspects of the discussed liability form. Some cases could be noted for curiosity, where more than one strict liability form should be applied. Ergo the product liability rule should be examined correlate to other strict liability forms. It occurred for instance, if a car were to cause damage to a third party through an inner defect. Strict liability rule is traditionally applicable for the damages caused by cars and other similar vehicles. However, the person who carries out an activity involving considerable hazards could not avoid the danger through having the car serviced the car, the cause would not certainly be beyond the realm of activity and the person could not therefore defend it. The liability of the producer can also be stated, thus the case of the claimant is under the cover of several liability forms. They caused the damage together, thus their liability is qualified as joint and several. Obviously, this is only theoretically noted, the claimant would certainly turn against the insurance company.

This liability form is usually reviewed in scope of economy, I wish to contrast some of the thoughts and treatises, which arise nowadays.

It shall be noticed, how the producer tries to handle the economic effects of the strict liability rule. The next citation serves as food for thought: could the goal of prevention be reached or not? It is worth invoking the relevant thesis of economics.

"A manufacturer produces automobile fuel additives that demand careful control over quality. If quality control is maintained at a high level, the chemical mixture in the product is correct, and it never causes damage to automobile engines. If, however, quality control is relaxed and allowed to fall to a low level, some batches of the chemical mixture will be flawed. A few of the cars using the flawed batch will be harmed; specifically, the engine will throw a rod and tear itself to pieces. After a rod is thrown, an alert mechanic can detect the cause of the harm by examining the car's fuel and other signs. The manufacturer determines that a high level of quality control costs more than the harm to some automobile engines caused by a low level of quality control, so the manufacturer adopts a low level of quality control. The owner of the damaged car sues the manufacturer and asks for punitive damages." 28

Some scholars argue against the rule of strict liability by asserting that consumers would not voluntary buy insurance at the price imposed by the tort liability system. ${ }^{29}$ Nowadays disputes are involved by similar issues between lawyers and scholars. One of these was published by Mitchell Polinsky and Steven Shavell reflecting the contributions of Professor Goldberg and Zipursky. ${ }^{30}$

28 Cooter, R.-Ulen, T.: Law and Economics. California, 2000, 288.

29 Ibid. 338

30 Polindsky, A. M.-Shavell, S.: A Skeptical Attitude about Product Liability is Justified: A Reply to Professors Goldberg and Zipursky. Harvard Law Review, 8 (2010) 123, 1919-1948. 
They analyzed empirical studies of the effect of product liability on product safety. ${ }^{31}$ In their article all of the empirical literature that they could locate was considered that sought to identify the effect of product liability on product accident rates, and they focused attention on studies that were concerned with specific products. These products were general aviation aircraft, motor vehicles, and childhood vaccines. In none of the studies did researchers find that increased product liability litigation resulted in a measurable decrease in accident rates. $^{32}$

The researchers failed to uncover a beneficial effect of product liability on product safety even though product liability litigation increased greatly during the periods studied (spanning the 1970s and 1980s).

In support of their point that individuals receive significant compensation for productrelated accidents from insurance, they observed that most Americans have private or public insurance coverage for medical expenses, loss of life, disability, and property damage. In the referred study was noticed that about $85 \%$ of the population possesses health insurance, approximately $78 \%$ of families own life insurance, at least one-third of the workforce holds some form of disability coverage, and $96 \%$ of homeowners have property insurance. They also observed in the article that individuals do not obtain as much compensation through the product liability system as might first appear. ${ }^{33}$ Benefit-cost evaluations are usually made, they cited in their article a number of studies that documented the high legal costs of tort liability. They also discussed indirect costs stemming from product price increases due to product liability. ${ }^{34}$

As Anthony J. Duggan stated ${ }^{35}$ that the economic efficiency reason for creating product liability is based on two grounds, the "pricing effects argument" and the "deterrence argument". The pricing effects argument means, that consumers systematically underestimate the risk of accidents relating to defective products. The imposition of this strict liability form will cause them to raise their prices, through the explicit price of the product includes a component for accident costs. The result should be a drop in demand to the optimal level, and a consequent reduction in the number of accidents. The deterrence argument could be described as follows. The imposition of liability on a manufacturer should persuade producers to avoid accidents (for example due to design improvements, provisions of warnings, or the adoption of testing procedures) and consequently less damages would be paid. Thus it will be worthwhile for the manufacturer to take precautions as long as the cost of this is less than the reduction achieved in the expected accident cost. If product liability were eliminated, the manufacturers should at least be liable in negligence (for instance because of the failure to take cost-justified accident precautions). However, plaintiffs may have difficulty in proving negligence and therefore, in the interests of effective deterrence, a strict liability regime may be warranted. The corollary of the deterrence argument in favour of manufacturers' liability is that in so far as there are costjustified accident precautions that can more easily be taken by the plaintiff (for example,

31 Ibid. 1956.

32 Goldberg and Zipursky claimed that they were selective in the empirical studies and choosing the examined goods, citing studies examined only the influence of the adoptation of modern product liablitiy law, without the fomer on negligance based rule.

33 Ibid. 1962.

34 Ibid. 1967.

35 Duggan, A. J.: Saying Nothing with Words. In: Ziegel, J. S.-Lerner, S. (eds): New Developements in International Commercial and Consumer Law. Oxford, 1998, 479-480. 
careful handling of the product), the manufacturer should not be liable. Otherwise, the plaintiff may have an insufficient incentive to take such precautions.

Nowadays the number of critical opinions concerning consumer liability is constantly increasing, these can easily be supported by the "legal achievements" of American consumerism, which would hopefully not be adopted into the European legal systems. It could be called "consumer overprotection". One of the favourite shocking cases of frivolous lawsuits involves McDonald's. An irresponsible woman spilled coffee on herself and then collected millions. The claimant, Stella Liebeck, suffered third-degree burns that required skin grafts and a week of hospitalization, because McDonald's served its coffee thirty degrees hotter than its competitors, too hot to drink but hot enough to burn. Prior to Liebeck's case, McDonald's had received more than seven hundred complaints about the temperature. Even then, the jury reduced Liebeck's compensatory damages by twenty percent because she was partly at fault, and the judge cut the jury's punitive damage award from USD 2.7 million to USD $480,000 .{ }^{36}$

In addition, the enforcement process should be shortly examined, it is enough to touch upon the probably most crucial questions concerning the enforcement of the rights. To be more specific the most vital problem is the out-of-court settlement of consumer disputes (or in other words: alternative dispute resolution), which should be officially endorsed (duly stating the financial background and the legal personality of these) as it is usually not worth taking up a lawsuit. For this reason, mediators and specialized quasi judicial bodies have been created. However, these solutions are faster, easier and cheaper than the traditional legal procedures, their decisions cannot be enforced in Hungary, because they are not real courts. It is worth to outlining the relating solutions of the British law, because this system seems to be fine tuned. If the consumers could not solve the problem through contacting the supplier, they can call a solicitor or a Citizen's Advice Bureau or they can turn to the Office of Fair Trading (hereinafter: OFT) helpline Consumer Direct. As the next step, one assistant of the Office will contact the supplier playing "the part of conciliator rather than advocate". ${ }^{37}$ After this they can contact the trade association. As we can see, there is a multi-level outof-court settlement, it is at the first sight similar to the Hungarian system, however we can highlight a relevant difference: the codes of practice, which were approved by the OFT. These optional rules are more likely to be followed, because the suppliers set these for themselves.

\section{Conclusion}

The question could be raised concerning the directive on product liability too: whether the consumer protection policy is a social political or economic political issue? We can imagine it as a policy, which addresses both of them, but it can hardly realise one of them. At first the European Union tried to fix the side-effects of free movement of goods and services, but later it became a separate, self-supporting legislation focusing on the interest of consumers. ${ }^{38}$ It should be added to my opinion, that contrary interests are usually articulated in the case of each legal instrument, depending on the intervention of the market regulators. As we could see in the first draft of the product liability directive, a higher protection level was

${ }^{36}$ Feinman, J. M.: Un-making Law. The Conservative Campaign to Roll Back the Common Law. Boston, 2004, 24.

37 Woodroffe-Lowe: op. cit. 187.

38 Cp.: Benacchio: op. cit. 202-203. 
established, than at present. This has been decreased under pressure from manufacturers. Hence the recent directive states only the minimum level of protection and gives the handling of this problem back to the judicature. In the countries, where the liability of manufacturers could effectively be handled within the frames of negligence, the aspect of the interpretation has not been changed substantially just by the directive. The directive could effect powerful changes, where the jurisdiction was not based on negligence, notwithstanding the fact, that in these countries the diversity of legal culture will challenge the possibility to achieve a common level of protection. 